\section{Commission lays foundations for rise in research spending}

\section{Declan Butler, Paris}

The European Commission says that it will allow "small and temporary" budget deficits to be run up by member states that are trying to boost spending on research.

The move is seen as lending support to a plan by the European Union (EU) to boost its total research and development (R\&D) spending from $1.9 \%$ of economic output to $3 \%$ by 2010 . Normally, member states that run budget deficits above target levels face huge fines from the commission.

Increased public spending on research is needed if the $\mathrm{EU}$ is to encourage more private investment; it is relying on industry to come up with twothirds of the proposed R\&D increase.

But even as the commission announced its offer, a survey by the European Round Table of Industrialists, a forum of 45 leaders of Europe's largest research-based companies, found that most of its members plan to increase research activity in the United States or Asia, rather than in Europe.

The commission's offer is part of an action plan released this week aimed at meeting the EU's R\&D target. The goal is seen as vital by Europe's politicians if the continent is to compete with the United States and Japan, which both spend about $3 \%$ of their economic output on R\&D.

The commission's plan calls for EU member states to agree measures to provide tax breaks for industry, to strengthen links between industrial and publicly funded research, to redirect public spending towards research and innovation, and to make careers in research more attractive. It also suggests that member states convert fragmented national research initiatives into Europewide programmes in critical technologies such as aerospace and nanotechnology.

But there is still a long way to go to meet the R\&D goal. Spain currently spends only $0.97 \%$ of its economic output on $\mathrm{R} \& \mathrm{D}$, lagging behind Italy $(1.04 \%)$ and Britain (1.84\%). France $(2.13 \%)$ and Germany $(2.52 \%)$ are closer to the target, but only Finland (3.37\%) and Sweden $(3.78 \%)$ surpass it.

The commission itself has little direct clout to enforce change, as member states set taxes and provide most public research funds. Officials say that it will rely instead on encouraging best practice in innovation and research policy, and on monitoring closely the performance of member states.

\title{
French researchers demand radical overhaul of funding
}

Declan Butler, Paris

Major reforms to decentralize France's research system were backed by most speakers at a high-level meeting on 28 April.

About 50 leading scientists and officials, including science minister Claudie Haigneré, met in Paris to discuss science policy. The meeting took place against a backdrop of protests by researchers against government budget cuts that are forcing the governmentrun laboratories that form the backbone of French research to deal with reductions of up to one-third in their operating budgets.

While attacking the cuts, speakers said that the time was ripe for a radical change in how French science is run. Philippe Kourilsky, director general of the Pasteur Institute in Paris said that that the malaise in the system is palpable.

Christian Bréchot, director general of INSERM, the national biomedical agency, was even blunter: "It's obvious that our model doesn't work," he said.

Many speakers expressed admiration for what is seen in France as the 'Anglo-Saxon model' of competitive grants based on peer review, as opposed to the French system in which most of the available money directly funds the laboratories of the main research organizations. Haigneré indicated that although such a model is not "directly transposable" to France, the government would like to introduce some elements of the system, turning the existing research

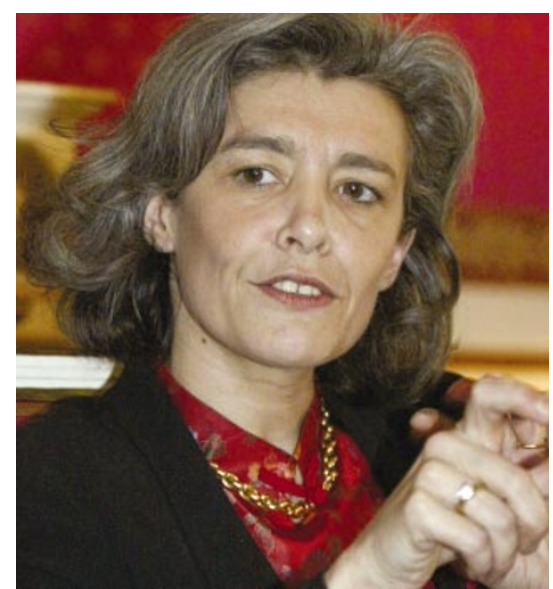

Claudie Haigneré: considering science reforms.

organizations into granting agencies.

Greater collaboration within the European Union was said by several speakers to be the best hope for France and its neighbours to strengthen their national research efforts, although concerns were expressed about the quality of existing European Commission research programmes.

Faced with a revolt by researchers, Prime Minister Jean-Pierre Raffarin recently promised that President Jacques Chirac's pledge to increase spending on research from $2.13 \%$ to $3 \%$ of economic output by 2010 would be met, with government spending on track to hit the target by 2007.

\section{Arizona institute names leader}

\section{Rex Dalton, San Diego}

Arizona State University (ASU) has hired a scientific heavyweight to head an ambitious, multidisciplinary research centre being built on its Tempe campus.

George Poste - former head of research at drug firm SmithKline Beecham and adviser

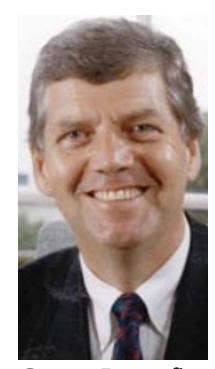

George Poste: five years to "to make things happen". to the British and US governments on bioterrorism — is set to be named this week as the new director of the Arizona Biodesign Institute (AzBio). Research projects at the institute are expected to include nanotechnology, materials science, robotics, information technology and drug-production methods.

Trained as a virologist and veterinarian in Britain,
Poste lives in Arizona. He is a member of the US government's Defense Science Board and chairman of its biodefence task force.

Fifty-eight-year-old Poste says that he has given the ASU "a minimum five-year commitment to make something special happen".

His appointment was due to be announced at a ceremonial groundbreaking on AzBio's first research building. The $\$ 70$-million structure is scheduled to be completed in late 2004, and the Arizona legislature is now debating a bill that would provide a further $\$ 185$ million for three more AzBio research buildings at the ASU.

"Poste is one of the leading scientists in the world, and there is no better person to build AzBio into a world-class centre," says Michael Crow, the ASU's president.

Charles Arntzen, a plant biologist who has been AzBio's interim director, will return to research, as was previously planned. 